\title{
TIPOLOGI IMAM SHALAT DI PROVINSI RIAU PERSPEKTIF SOSIOLOGI HUKUM ISLAM
}

\section{Ismardi dan Arisman}

Universitas Islam Negeri Sultan Syarif Kasim Riau, Indonesia

Ismardi_onga@yahoo.co.id

\begin{abstract}
Abstrak
Imam shalat fungsi dan perannya tidak hanya sebatas memimpin shalat berjama`ah saja. Lebih dari itu, seorang imam mesti memiliki ilmu pengetahuan tentang itu, sehingga jika ada jamaah yang memiliki permasalahan dalam hal keagamaan, imam tersebut bisa menjawab dan memberikan solusi. Imam Shalat merupakan sosok ulama yang berhubungan dan berinteraksi dengan lingkungan sosialnya. Dalam berhubungan dengan lingkungan, para imam melakukan berbagai aktivitas keulamaannya dengan sadar dan atas kemauan serta sesuai dengan motif dan keinginannya. Dengan demikian tipologi Imam shalat di provinsi Riau dapat dibagi ke dalam: Pertama, imam kompromiskondisonal. Dalam kategori ini gaya seorang imam lebih merupakan hasil kompromi dan afirmasi dari keinginan jamaah; Kedua, imam "Citra-Sensasional". Ketiga, Imam Mandiri, Berbeda dengan kategori imam citra, mereka yang termasuk dalam kategori ini tidak berpretensi untuk menunjukkan kehebatan dan keunggulan dirinya saat menjadi imam shalat. Keempat, Imam Ideal-Literalis. Imam dalam kategori ini berusaha semaksimal mungkin melaksanakan shalat sesuai kaidah teks hadis termasuk di dalam shalat berjamaah.
\end{abstract}

Kata Kunci: Imam, Shalat, dan Sosiologi Hukum

\section{Pendahuluan}

Fakta di lapangan menyebutkan bahwa ada beberapa kesenjangan yang tidak seharusnya terjadi dalam peran dan tugas seorang imam shalat. Di antaranya, masih ada imam shalat fungsi dan perannya hanya sebatas memimpin shalat berjama'ah saja. Bahkan dalam melaksanakan shalat berjama`ahpun masih salah dalam bacaan-bacaan yang termasuk rukun qauli dalam shalat. Seperti sulit membedakan dalam bacaan alFatihah antara huruf ain dan alif, antara huruf sin dan shad, dan antara mad ashli dan mad thabi i. Bahkan pada Q.S. al-Fatihah ayat 5: اياك نعبد bacaan yang seharusnya 
dibaca نعبد (na budu), namun dibaca dengan memanjangkan harakat $d u u$ sehingga seakan-akan ada huruf waw yang sukun sehingga bacaannya menjadi اياك نعبدو.

Di samping itu, juga masih ada imam shalat hanya memiliki modal keberanian menjadi imam tanpa memiliki ilmu pengetahuan tentang itu, sehingga jika ada jama'ah yang memiliki permasalahan dalam hal keagamaan, imam tersebut tidak bisa menjawab dan memberikan solusi. Hal ini pada prinsipnya disebabkan penunjukkan imam shalat tidak melalui seleksi, baik secara administrasi maupun keilmuan. Hal inipun juga disebabkan pengurus Masjid menjadikan ta`mir Masjid sebagai imam shalat dengan tidak mempertimbangankan aspek kefasihan, pemahaman terhadap alQur'an dan al-Sunnah, ilmu keislaman, dan usianya.

Selain dari itu, imam shalat kurang memahami kondisi sosial kehidupan masyarakat, baik dari segi pendidikan, tingkat sosial, pekerjaan, bahkan kondisi kesehatan jama'ah di sekitar Masjid. Sehingga masih ada Masjid yang tak seimbang antara jamaah yang selalu datang ke Masjid dengan jumlah masyarakat yang berdomisili di sekitar Masjid disebabkan karena imamnya belum dapat menarik minat jama'ah untuk memakmurkan Masjid.

Seperti manusia pada umumnya, imam shalat atau ulama adalah makhluk yang bersifat individual sekaligus bersifat dan memerankan fungsi sosial. Sebagai makhluk sosial, imam shalat merupakan sosok ulama yang berhubungan dan berinteraksi dengan lingkungan sosialnya. Dalam berhubungan dengan lingkungan, ulama melakukan berbagai aktivitas keulamaannya dengan sadar dan atas kemauan serta sesuai dengan motif dan keinginannya. Tindakan seperti ini menurut Weber di sebut tindakan sosial.

Sebagai bapak sosiologi, Weber dikenal dengan konsep (teori) tindakan sosial-nya. Menurut Weber dalam Walsh dan Lehnert (1972: 15), tindakan sosial adalah segala perilaku manusia ketika dan sejauh individu memberikan suatu makna subjektif terhadap perilaku tersebut. Lebih lanjut, perintis sosiologi kelahiran 
Jerman tahun 1864 tersebut mengatakan bahwa tindakan bermakna sosial, sejauh berdasarkan makna subjektif yang diberikan oleh individu.

Dengan menggunakan perspektif tindakan sosial Weber, fenomena komunikasi yang dilakukan seorang ulama dalam memimpin shalat dan ketika melakukan aktivitas dalam melakukan ritual keagamaan dapat dikategorikan sebagai tindakan sosial, karena hal tersebut dilakukan dengan penuh kesadaran oleh ulama. Hal ini memenuhi kriteria lain dari tindakan sosial, yaitu "when the individual orients his or her acts to others besides self" (Joel M. Charon, 1979: 128). Bagi Weber dalam Deddy Mulyana (2001: 61), tindakan manusia pada dasarnya bermakna, melibatkan penafsiran, berpikir, dan kesengajaan. Tindakan sosial adalah tindakan yang disengaja, yakni disengaja bagi orang lain dan bagi sang aktor sendiri, di mana pikiranpikirannya aktif saling menafsirkan perilaku orang lain, berkomunikasi dan berinteraksi antara satu dengan yang lainnya.

\section{Pengertian Imam}

Kata imam dalam bahasa Arab adalah pemimpin, pemuka (Ahmad Warson Munawir, 1997: 40). Sedangkan imam menurut istilah adalah pemuka di dalam berbagai aspek kehidupan umat Islam (IAIN Syarif Hidayatullah, 1992: 420). Imam dapat pula diartikan:

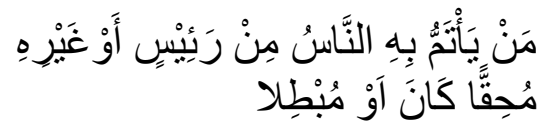

"Orang yang dijadikan ikutan orang banyak sehingga menjadi pemimpin atau selain itu, baik dalam kebenaran maupun kebatilan"'(Jaib, 1998: 24).

Sedangkan pengertian imam dalam konteks shalat adalah pimpinan dalam shalat jama'ah, baik dalam kedudukannya yang tetap maupun dalam keadaan yang sementara, sang imam berdiri paling depan dari barisan jama'ah shalat (Glasse, 1999: 166-167). Imam juga dapat diartikan pemimpin shalat pada saat dilakukan secara bersama-sama, ikutan, yang diikuti (Tri Rama K., T.th.: 182).

Berdasarkan pengertian imam di atas, maka kedudukan imam sangat urgen dalam pelaksanaan shalat berjama'ah, di antaranya:

a. Sebagai Pemimpin Shalat 
Pemimpin yang dimaksud adalah semua gerakan dan bacaan dalam shalat dikomandoi oleh imam. Dengan demikian, kedudukan imam sangat penting dalam pelaksanaan shalat berjama'ah karena semua bacaan dan gerakan yang dilakukan imam menjadi ikutan makmum. Sebagaimana sabda Rasulullah SAW: ${ }^{1}$

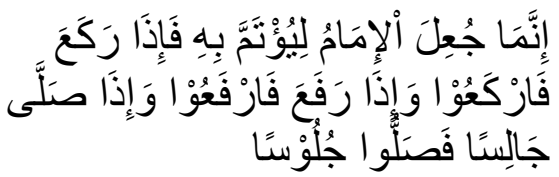

"Sesungguhnya imam itu dijadikan hanyalah untuk menjadi yang diikuti, apabila imam rukuk maka rukuklah, jika imam mengangkat tangan (takbir) maka angkatlah tangan, dan jika imam shalatnya duduk maka shalatlah dengan duduk juga”.

Berdasarkan hadis di atas, penulis menarik kesimpulan bahwa imam dalam pelaksanaan shalat adalah orang yang telah memenuhi kriteria untuk menjadi

1al-Imam al-Hafizh Abi al-Fadhl Jalal al-Din Abd al-Rahman al-Suyuthi, AlTausyih Syarh al-Jami al-Shahih, Jilid 2, Kitab al-Shalat Bab Fadh Shalat al-Jama'ah, Hadis no. 688 (al-Mamlakah al-Arabiyah alSu`udiyah: Maktabah al-Rusyd, 1419 H/1998 M), 707; Lihat juga, Ibn Ruysd, Bidayah al- pemimpin dalam shalat berjamaah, baik kedudukannya menjadi tetap atau sementara dan posisinya di depan jamaah.

Seorang imam biasanya adalah orang yang baik dalam shalatnya, orang-orang yang berhati-hati mengerjakan shalat, yang memperbaiki cara-cara shalat, agar mendapat ganjaran orang-orang yang menjadi pengikut (makmum) dan bukan mendapat dosa dari kesalahan orang yang berada di belakangnya (Ibnu Hanbal, 1974: 35).

Keberadaan imam dalam shalat tidak lepas adanya shalat yang dilakukan secara berjamaah, yaitu shalat yang dilakukan dua orang atau lebih secara bersamasama dengan ketentuan tertentu, di mana seorang menjadi imam dan yang lainnya menjadi makmum. Maka para jamaah bahu-membahu antara satu dengan yang lain, dengan

Mujtahid wa Nihayah al-Muqtashid (t.tp.: Dar al-Màrifah, 1402 H/1982 M), 146; Lihat juga, al-Imam al-Nawawi, Syarah Shahih Muslim, jilid 1, Kitab al-Shalat Bab I timam al-Ma'mum al-Imam, Hadis no. 411 (Indonesia: Maktabah Dahlan, 1374 H/1954 M), 308. 
membentuk satu barisan tentara yang siap melaksanakan perintah dari komandannya. Dengan berdiri satu barisan dan melakukan gerakan-gerakan secara serempak, maka perasaan akan kesatuan tujuan akan tertanam, yaitu mengabdi kepada Allah dengan sedemikian rupa, sehingga bergerak secara serempak, serempak mengangkat tangan, serempak menggerakkan kaki, dan gerakan-gerakan shalat lainnya secara sempurna (alMaududi, 1984: 140-141).

Dalam shalat berjama'ah, seorang makmum harus mengikuti imam dalam hal berdiri, rukuk, sujud, duduk, dan seterusnya. Dengan demikian, adanya ikatan shalat seorang makmum dengan shalat seorang imam, yang disebut dengan imamah. Ikatan ini lahir dari makmum sebagai pertanda bahwa makmum mengikuti imam dalam shalat. Oleh karena itu, shalat imam tidak ikut batal apabila shalat makmum batal. Namun, shalat makmum ikut batal jika shalat imam batal, karena makmum telah mengikatkan shalatnya kepada shalat imam.

Imamah dalam shalat dapat terwujud dengan satu orang makmum atau lebih. Tidak ada perbedaan antara pria ataupun wanita. Menurut Hanafiah dan Syafìyah, imamah itu sah sekalipun makmumnya hanya seorang anak kecil yang mumayiz. Malikiyah dan Hanabilah menyangkal pendapat tersebut dengan menyatakan bahwa shalat jamaah anak kecil bersama seorang imam secara berduaan saja tidak sah (al-Jaziri, 2004: 85).

b. Sebagai Penentu Sah dan Tidaknya Shalat Berjama'ah

Shalat berjama'ah terdiri dari imam dan makmum. Imam adalah pemimpin dalam shalat yang harus diikuti oleh makmum, sedangkan makmum adalah orang yang harus mengikuti imam dalam setiap gerakan dan bacaan shalat. Dalam shalat berjamaah peran imam sebagai penentu keabsahan shalat berjamaah. 
Salah satu kaidah fiqh mengatakan:

$$
\text { إِذَا صَنَّ الْإِمَامُ صَحَّتَ الْجَمَاعَةُ }
$$

"Apabila sah shalatnya seorang imam, maka sah shalat berjamaahnya".

c. Mengemban Tugas Mulia dan Suci

Tugas seorang imam merupakan tugas keagamaan yang mulia dalam rangka memakmurkan masjid. Hal ini juga telah diemban sendiri oleh Rasulullah SAW, begitu juga dengan al-Khulafaur al-Rasyidin. Dalam konteks memakmurkan masjid, peran imam sangat dibutuhkan untuk menarik minat jama'ah ramai-ramai mendatangi masjid untuk melaksanakan shalat berjama'ah.

Perintah memakmurkan masjid ini terdapat dalam Q.S. al-Taubah (9): 18:

क目(;

र2 2 (:) $\rightarrow$ (3) Х(9)

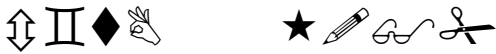
कबत है के त * or ar QP.

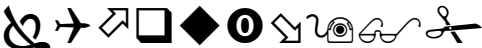
$\triangleright \square$

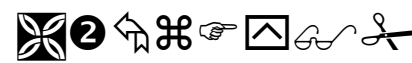

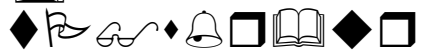

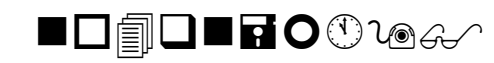
(7) क्षेत्र क्ष 口口闻口・望 $\square$ 8 206 of $\Leftrightarrow$ por $2 \circ \square$

$\cdot$ - वे(ग) (3) (3) (6) 要 1 G \& (6) $\odot \rightarrow \rightarrow$ 스은 $\Omega \square \mathbb{Q D}$

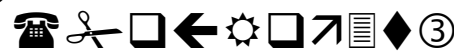
भIID है

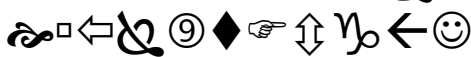

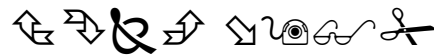
"Hanya yang memakmurkan masjid-masjid Allah ialah orang-orang yang beriman kepada Allah dan hari Kemudian, serta tetap mendirikan shalat, emnunaikan zakat dan tidak takut (kepada siapapun) selain kepada Allah, Maka merekalah orang-orang yang diharapkan Termasuk golongan orang-orang yang mendapat petunjuk".

\section{Syarat-syarat Menjadi Imam}

Adapun persyaratan untuk dapat menjadi imam dalam shalat adalah sebagai berikut: a) Beragama Islam (muslim); b) Akil baligh. Seseorang yang sudah akil baligh dapat menjadi imam bagi yang akil baligh dan yang belum akil baligh. Orang yang telah akil baligh, menurut mazhab Hanafi, Maliki, Syafi'i, dan Hanbali, tidak sah mengikuti seorang imam yang masih 
anak-anak kendatipun ia mumayyiz (dapat membedakan yang baik dan yang buruk), kecuali pada shalat sunnah; c) laki-laki. Orang laki-laki dapat menjadi imam bagi jamaah lakilaki ataupun jamaah perempuan. Adapun terhadap jamaah perempuan, perempuan boleh menjadi imam; d) berakal. Tidak sah jika orang gila menjadi imam. Namun, apabila kadang-kadang sakit dan kadangkadang sehat, ia sah menjadi imam ketika sehat; e) diutamakan orang yang terbaik bacaannya atau yang terpandai di bidang agama atau tertua dalam usia; f) sehat dari penyakit yang akan menjadikan shalatnya mudah rusak, seperti orang yang wudhu'nya mudah batal (Tim Penyusun, 2005: 168).

Imam shalat adalah pemimpin yang menjadi panutan para makmum. Maka seorang imam haruslah betulbetul orang yang layak dan pantas untuk memimpin dalam shalat. Tidak diperbolehkan menjadi imam shalat bagi seorang wanita, banci, orang kafir, gila, dan bodoh (al-Qurtubi, t.th.: 223; An-Nawawi, t.th.: 21).

Sebagaimana dijelaskan di atas, bahwa ketentuan imam shalat tidak diatur dalam al-Qur'an. Ketentuan siapa yang berhak menjadi imam dalam shalat dapat kita lihat dalam hadis riwayat Imam Abu Daud sebagai berikut:

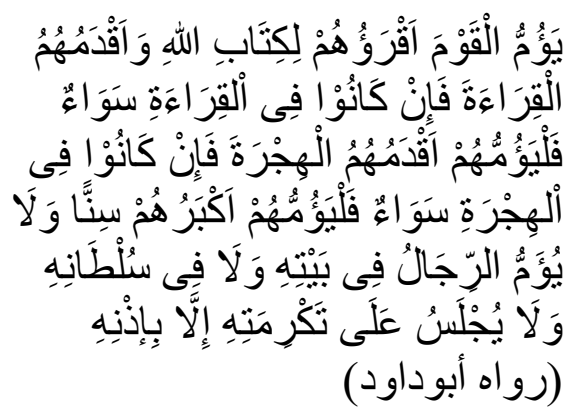

"Orang yang lebih menguasai (isi al-Qur'an) dan yang lebih menguasai bacaan (ilmu qira'at dan bacaanya lebih bagus) yang lebih berhak menjadi imam shalat, apabila dalam penguasaan bacaan al-Qur'an berkualitas sama, maka yang lebih berhak menjadi imam adalah orang yang lebih awal melakukan hijrah (ke Madinah), apabila dalam hal berhijrah juga sama, maka yang lebih berhak mejadi imam adalah yang usianya lebih tua. Seseorang tidak boleh diimami (orang lain) di rumah dan daerahnya, dan tidak mempersilahkan orang lain duduk di tempat yang dimuliakan 
itu kecuali atas izinnya” (HR. Abu Daud). ${ }^{2}$

Dari hadis di atas, dapat kita pahami bahwa ada beberapa pertimbangan dalam menentukan imam shalat. Pertimbanganpertimbangan tersebut adalah penguasaan bacaan dan ilmu alQur'an, hijrah, dan usia. Imam Syafi' $i$ berpendapat bahwa orang yang lebih berhak menjadi imam shalat adalah orang yang paling bagus dalam penguasaan ilmu dan bacaan alQur'an ( $\left.a q^{\prime} r a\right)$, serta orang yang lebih menguasai fiqh (afqah) (al-Syirazi, 2002: 143).

Jika sama dalam posisi tersebut, menurut Imam Syafi'i yang berhak adalah orang yang lebih mulia (alAsyraf), apabila kemuliaannya pun sama, maka yang lebih berhak adalah orang yang lebih dahulu melakukan hijrah. Apabila dalam hal hijrah sama, maka yang berhak adalah yang lebih tua umurnya.

Dalam hadis tersebut juga mengisyaratkan bahwa seseorang yang bacaan al-Qur'annya tidak bagus

2 Imam Abu Daud, Ain al-Ma'bud Syarh Sunan Abi Daud, Kitab al-Shalat Bab Man Ahaqqu bi al-Imamah, Juz 2, hadis no. tidak sah diangkat menjadi imam dalam shalat. Yang dimaksud dengan bacaan yang tidak bagus/ tidak fasih ialah keadaan seseorang yang mengakibatkannya tidak mampu membaca al-Quran sesuai dengan yang semestinya. Misalnya, bacaannya mengubah pengertian ayat al-Qur'an, seperti mengucapkan ihdinash-shirathal mustaqim (tunjukilah kami jalan yang lurus) dengan bacaan ihdinas-siraqal mustaqim (tunjukilah kami pencuri yang lurus) (Tim Penyusun, 2005: 705).

Keharusan seorang imam memiliki kemampuan membaca dengan fasih dinyatakan Rasulullah SAW dalam beberapa hadisnya, antara lain:

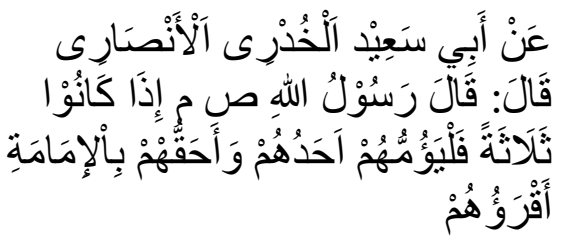

"Dari Abu Sa'id ra ia menceritakan bahwa Rasulullah SAW bersabda: "Jika mereka bertiga, maka hendaklah mereka mengangkat sebagai imam salah seorang di antara mereka, dan yang lebih berhak di antara

578 (Beirut: al-Maktabah al-Salafiyah, t.th), 291. 
mereka ialah orang yang lebih fasih bacaannya" (Imam Abu Daud, t.th.: 292).

\section{Fuqaha berbeda pendapat} dalam mengutamakan antara orang yang lebih baik bacaan al-Qur'annya dan yang lebih baik pemahaman fiqhnya. Menurut imam Abu Hanifah dan imam Ahmad bin Hanbal, diutamakan orang yang lebih baik bacaan al-Qur'annya. Sebagai alasannya, mereka mengemukakan hadis riwayat Abu Daud di atas yang mengutamakan orang yang lebih fasih bacaannya (aqra`uhum). Adapun imam Syafi'i berpendapat bahwa orang yang lebih dalam pengetahuannya tentang fiqh lebih diutamakan sebagai imam. Imam Syafi’i juga mengemukakan alasan yang sama, tetapi mengartikan aqra `uhum dengan "orang yang lebih tahu hukum Islam". Pengetahuan tentang hukum Islam menurutnya, lebih diutamakan dalam masalah imamah daripada hanya kefasihan membaca al-Qur'an.

Seorang muslim pemilik rumah atau wilayah lebih berhak menjadi imam dalam shalat yang dilaksanakan di rumah atau wilayahnya. Dengan kata lain, tuan rumah lebih berhak menjadi imam daripada pendatang, selama ia memenuhi persyaratan sebagai imam. Sabda Rasulullah SAW. (al-Nawawi, t.th.: 473):

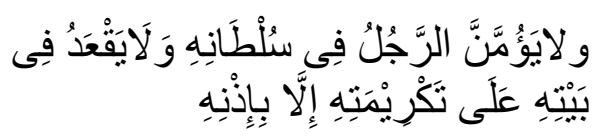

"Seseorang tidak boleh diimami (orang lain) di rumah dan daerahnya, dan tidak mempersilahkan orang lain duduk di tempat yang dimuliakan itu kecuali atas izinnya".

Menurut ulama Hanafiah orang yang paling berhak menjadi imam adalah orang yang ada dalam urutan berikut ini: (1) Orang yang paling alim (mengetahui) tentang hukumhukum shalat, baik yang berkaitan dengan sahnya shalat maupun batalnya shalat. Dengan syarat ia dapat menjahui perbuatan-perbuatan keji yang nyata. Kemudian yang paling baik bacaannya dan tajwidnya; (2) Orang yang paling wara' (orang yang banyak menjahui maksiat serta hal-hal yang syubhat); (3) Orang yang lebih dahulu masuk Islam; (4) Orang yang paling tua usianya. Jika keduanya sama-sama muslim yang taat, dipilih yang paling baik 
akhlaknya; (5) Orang yang paling tampan wajahnya; (6) Orang yang paling mulia keturunannya; dan (7) Orang yang paling bersih pakaiannya (al-Jaziri, 2004: 109).

Jika orang-orang tersebut sama dalam hal tersebut, hendaknya diundi antara mereka jika berebut untuk menjadi imam. Jika tidak, hendaklah mereka mempersilahkan siapa saja yang mereka kehendaki. Jika terjadi perselisihan dan tidak rela dengan cara undian, hendaknya mempersilahkan orang yang dipilih oleh mayoritas. Jika mayoritas memilih orang yang tidak berhak menjadi imam, berarti mereka telah melakukan sesuatu yang tidak baik, tetapi tidak berdosa. Ini semua terjadi apabila di antara mereka itu tidak ada penguasa, tuan rumah tempat mereka berkumpul, atau orang yang bertugas menjadi imam. Jika semua ada, hendaklah mereka mempersilahkan penguasa. Jika tidak ada semua, tuan rumah berhak secara mutlak. Hal yang sama juga terhadap imam tetap masjid. Jika di rumah itu terdapat pemiliki rumah dan penyewa rumah, yang lebih berhak untuk menjadi imam adalah penyewa rumah.
Ulama Syafi'iyah berpendapat bahwa yang berhak untuk menjadi imam ialah berdasarkan urutan berikut ini: (1) Pemimpin di tempat wilayahnya; (2) Imam tetap; (3) Orang yang bertempat tinggal di suatu tempat dengan cara yang hak (benar) jika ia bisa menjadi imam. Jika di antara mereka tidak ada orang tersebut, hendaklah mereka mempersilahkan orang yang paling paham tentang hukum-hukum Islam atau fakih; (4) Orang yang paling fasih bacaannya; (5) Orang paling zuhud; (6) Orang yang paling wara'; (7) Orang yang terlebih dahulu berhijrah; (8) Orang yang paling banyak menjalankan sunnah dalam Islam; (9) Orang yang paling mulia keturunannya; (10) Orang yang paling baik tingkah lakunya; (11) Orang yang paling bersih pakaiannya; (12) Orang yang paling baik suaranya; (13) Orang yang paling baik postur tubuhnya; dan (14) Orang yang sudah menikah (al-Jaziri, 2004: 110).

Jika mereka sama dalam semua hal tersebut, hendaknya diundi antara mereka. Orang lebih berhak menjadi imam boleh mempersilahkan yang 
lainnya untuk menjadi imam selama majunya orang yang lebih berhak itu bukan karena sifat yang dimilikinya, misalnya ia adalah seorang yang paling alim maka ia tidak boleh melakukan yang demikian itu.

Menurut ulama Malikiyah bahwa apabila ada suatu jama'ah berkumpul, sedangkan masingmasing dari mereka pantas untuk menjadi imam, disunnahkan untuk mendahulukan seorang di antara mereka (sesuai dengan urutan berikut): (1) Penguasa atau wakilnya sekalipun ada orang lain yang lebih alim dan lebih utama; (2) Imam tetap di masjid tersebut; (3) Tuan rumah, tetapi penyewa rumah itu lebih didahulukan daripada pemilik rumah. Jika tuan rumah itu wanita dan ia yang berhak atas rumah itu, ia wajib mewakilkan kepada orang lain karena imamah seorang wanita (terhadap) laki-laki tidak sah; (4) Orang yang lebih mengetahui tentang hukumhukum shalat; (5) Orang yang lebih mengetahui tentang ilmu hadis, baik dari segi periwayatan maupun hafalan; (6) Mendahulukan orang yang adil daripada orang yang tidak jelas keadaannya; (7) Orang yang lebih fasih bacaannya; (8) Orang yang lebih banyak melakukan ibadah; (9) Orang yang lebih dahulu masuk Islam; (10) Orang yang lebih mulia keturunannya; (11) Orang yang paling baik akhlaknya; dan (12) Orang yang paling baik pakaiannya, yaitu orang yang menggunakan pakaian baru yang boleh dipakai (mubah).

Jika mereka mempunyai derajat yang sama dalam urutan di atas, hendaknya mereka mempersilahkan orang yang paling wara' di antara mereka. Jika mereka sama dalam semua hal itu, hendaklah diundi antara mereka, kecuali apabila mereka rela mempersilahkan seorang di antara mereka. Jika ada di antara mereka berebut untuk menjadi imam dengan maksud demi ketinggian derajat dan kesombongan, gugurlah hak mereka secara keseluruhan untuk menjadi imam.

Menurut ulama Hanabilah bahwa tingkatan yang paling berhak untuk menjadi seorang imam adalah sebagai berikut: (1) Orang yang paling fakih dan paling baik bacaannya; (2) Orang yang fakih dan paling baik bacaannya; (3) Orang 
yang paling baik bacaannya saja sekalipun ia bukan seorang fakih asalkan ia mengetahui tentang hukum-hukum shalat; (4) Orang yang hafal al-Qur'an dengan tetap memperhatikan yang paling fakih untuk bertindak sebagai imam shalat;

(5) Orang yang hafal al-Qur'an dengan tetap memperhatikan yang fakih untuk bertindak sebagai imam; (6) Orang yang hafal al-Qur'an dengan tetap memperhatikan yang mengetahui fiqh shalat; (7) Orang yang bisa membaca (sekalipun) tidak mengetahui fiqh shalatnya. Jika mereka sama-sama tidak bisa membaca, hendaklah mereka mendahulukan yang lebih mengetahui tentang hukum-hukum shalat. Jika mereka sama-sama bisa membaca dan memahami, hendaklah mereka mendahulukan yang tertua, yang keturunannya lebih mulia dan lebih dahulu berhijrah. Orang yang lebih dahulu masuk Islam hukumnya sama dengan orang yang lebih dahulu berhijrah; (8) Orang yang paling takwa; dan (9) Orang yang paling wara' (al-Jaziri, 2004: 110).

Apabila sama tingkatan mereka dalam hal-hal yang telah disebutkan di atas, hendaklah imam di rumah adalah tuan rumah (shahibul bait) jika ia memenuhi syarat untuk menjadi imam, sedangkan di masjid maka yang paling berhak adalah imam tetap sekalipun ia seorang hamba. Hal ini berlaku apabila tidak ada penguasa yang menghadiri rumah atau masjid tersebut. Jika ada penguasa, ia yang lebih berhak.

Dengan demikian, yang paling berhak menjadi imam shalat secara berurutan adalah: (1) Orang yang paling pandai membaca al-Qur'an; (2) Orang yang paling mengerti tentang sunnah Nabi SAW; (3) Orang yang paling pertama melaksanakan hijrah; (4) Orang yang lebih dahulu masuk Islam; (5) Orang yang lebih tua usianya; dan (6) Tuan rumah dan penguasa lebih berhak menjadi imam.

Abu A'la al-Maududi (1984: 142-143) merumuskan ketentuan imam shalat ini secara lebih luas dan komprehensif, yaitu: (a) Salih dan Baik. Ia mewajibkan bahwa orang yang menjadi imam adalah orang baik, tinggi ilmunya, lebih banyak pengetahuannya tentang al-Qur'an daripada orang lain, serta paling tua umurnya, sebagaimana dijelaskan 
dalam hadis; (b) Mewakili Mayoritas. Diwajibkan imam adalah orang yang banyak disukai dan diterima oleh para jama'ah, hampir tidak mempunyai musuh satupun dalam jama'ah tersebut; (c) Bersimpati Kepada Pengikut. Diwajibkan seorang imam pandai membaca situasi jama'ah. Ia tidak boleh membaca surat-surat panjang, melakukan rukuk dan sujud berlama-lama sementara jama'ahnya terdiri daripada orang tua, orang sakit, lemah serta orang-orang sibuk yang ingin cepat-cepat menyelesaikan shalatnya dan kembali kepada pekerjaannya; (d) Imam Harus Mundur Bila Tidak Mampu Melaksanakan Tugas. Apabila seorang imam yang sedang memimpin shalat mengalami suatu hal yang menyebabkan ia tidak dapat menjalankan tugasnya, maka ia harus segera mengundurkan diri dan menempatkan salah seorang yang berada di belakangnya untuk menggantikan kedudukannya; (e) Kepatuhan Sepenuhnya Kepada Imam. Diwajibkan bagi makmum untuk mengikuti perbuatan-perbuatan yang dilakukan oleh imam dengan sempurna, dalam hal ini makmum tidak boleh mendahului gerakan imam; (f) Mengoreksi Kesalahan. Apabila imam mengalami kekeliruan gerakan dalam memimpin shalat, maka para jama'ah harus memperingatkannya dengan mengucap tasbih "subhanallah". inilah cara untuk mengoreksi kesalahan imam; dan (g) Tidak boleh patuh dalam dosa. Makmum tidak boleh patuh apabila imam berlawanan dengan sunnah Rasul, imam mengubah cara shalat atau dengan sengaja membaca ayat-ayat al-Qur'an secara salah, atau dalam shalat mengerjakan perbuatan-perbuatan syirk atau kufr, atau melakukan dosa yang terang, maka jama'ah wajib menghentikan shalat dan memisahkan diri dari imam.

Shalat jama'ah menurut alMaududi merupakan miniatur atau latihan kecil untuk menjalankan sebuah pemerintahan yang besar. Suatu latihan yang harus dilakukan lima kali sehari di setiap shalat-shalat.

Menurut Hasbi ash-Shiddieqy (1954: 327) sifat-sifat imam dalam shalat berjamaah adalah: Hendaklah menunaikan amanahamanah Allah SWT, yakni 
memelihara diri dari fusuq (kefasikan), dari dosa besar dan dari berkekalan atas dosa kecil; (2) Hendaklah memelihara diri dari `ujub dan dari takabbur sebab sifat ini akan menghilangkan pahala dan mendatangkan dosa; dan

Hendaklah memperoleh keridhaan orang-orang yang diimaminya dan hendaklah juga ia mempunyai hak menjadi imam. Jika makmumnya tidak ridha kepadanya, maka hendaklah ia menarik diri.

Dengan demikian, minimal sifat seorang imam dalam mengimami jama'ah disyaratkan: (1) Mampu menunaikan shalat. Dalam hal ini jika seorang imam mengalami gangguan tentang kesanggupannya, maka hendaklah ia menggantikan dirinya dan mundur ke dalam shaf menjadi makmum; (2) Mengetahui hukumhukum shalat. Dalam hal ini seorang imam hendaklah mengetahui syarat sah shalat, rukun shalat, pembatal shalat, dan segala hal yang berhubungan dengan pelaksanaan shalat; (3) Mempunyai akal yang sehat; dan (4) Bacaan al-Qur'annya bagus dan benar.
Di samping itu ada ulama yang mensyaratkan imam itu di antaranya: 1) tidak fasiq; 2) terkenal keadaannya; 3) tidak tertuduh melakukan kejahatan; 4) tidak memiliki penyakit menular; dan 5) tidak menghendaki upah (Hasbi ash-Shiddieqy, 1954: 329).

\section{Pembahasan}

Kedudukan imam sangat urgen dalam kehidupan masyarakat sebagaimana urgennya imam dalam pelaksanaan shalat berjama'ah. Hal ini dapat dilihat di mana semua gerakan dan bacaan dalam shalat dikomandoi oleh imam. Begitu juga dalam kehidupan masyarakat, perkataan imam menjadi rujukan dan "pelita" dalam menyinari masyarakat dengan ilmu agama.

Imam dalam pelaksanaan shalat adalah orang yang telah memenuhi kriteria untuk menjadi pemimpin dalam shalat berjama'ah, baik kedudukannya menjadi tetap atau sementara dan posisinya di depan jama'ah. Ini juga menjadi indikasi bahwa kedudukan imam dalam kehidupan masyarakat dapat dijadikan pemimpin, karena pada 
dirinya terhimpun beberapa kriteria untuk menjadi seorang pemimpin.

Seorang imam biasanya adalah orang yang baik dalam shalatnya, orang-orang yang berhati-hati mengerjakan shalat, yang memperbaiki cara-cara shalat, agar mendapat ganjaran orang-orang yang menjadi pengikut (makmum) dan bukan mendapat dosa dari kesalahan orang yang berada di belakangnya. Artinya, seorang imam mestilah berhati-hati dalam setiap ucapan dan tingkah laku di tengah kehidupan masyarakat. Dengan demikian, seorang imam idealnya adalah pribadi yang mesti menjadi suri tauladan.

Menjadi imam shalat merupakan suatu kehormatan tersendiri, jika kita umpamakan sebagai miniatur pemerintahan maka imam shalat adalah pemimpin dalam suatu Negara atau pemimpin dalam suatu masyarakat. Dia telah mendapatkan amanah untuk memimpin jalannya shalat dari awal sampai akhir. Peran sebagai pemimpi inilah yang kemudian tidak bisa dihindari oleh seseorang yang menjadi imam tersebut.
Maka dengan segala otoritas yang dimilikinya, timbul perbedaan tipikal dari masing-masing Imam yang akan berangkat dari pembacaan atas situasi yang berlainan yang ia perankan di antara mereka. Berdasarkan wawancara dan pengamatan dan temuan di lapangan penulis membuat tipologi dari masing-masing informan saat ia memerankan menjadi seorang imam diantaranya.

Pertama, imam kompromiskondisonal. Dalam kategori ini gaya seorang imam lebih merupakan hasil kompromi dan afirmasi dari keinginan jama'ah. Mereka mempunyai pandangan bahwa ketika ditunjuk sebagai seorang imam maka ia tidak boleh mengecewakan. Oleh karena itu, gaya kepemimpinan dalam shalatnya amat kondisional, baik dari segi lamanya waktu maupun pilihan ayat yang dipakai dalam shalat.

Di sini seorang imam harus juga dituntut untuk bisa membaca selera jama'ah, yang barangkali berbeda antara satu tempat dengan tempat lainnya.

Dalam hal tata cara berpakaian, mereka juga selalu menyesuaikan, 
seperti halnya memakai sarung, peci, sajadah, membawa tasbih perlu diperhatikan dan disesuaikan dengan kondisi masyarakat dan kebisaan yang dipakai di sekitar Masjid tersebut. Bahkan sangat kompromisnya, tipologi imam ini pun biasa memakai lintas fiqh demi memuaskan makmum. Mereka terkadang memakai qunut, namun di tempat lain mereka juga tidak memakai.

$$
\text { Kedua, imam "Citra- }
$$

Sensasional". Dalam penulisan ini digunakan istilah citra-sensasional, karena seorang imam dalam menjalankan tugasnya cenderung bersikap menunjukkan kesenangan dan menjaga sekaligus menunjukkan keunggulan, sensasi, dan kehebatan dalam memimpin shalat jama'ah. Bagi mereka memimpin shalat berarti kesempatan untuk menunjukkan kehebatan dirinya, baik dari segi hafalan maupun dari segi keindahan bacaan yang menurutnya dapat memikat pendengar.

Dalam berbusanapun mereka cenderung memakai pakaian yang sesuai dengan citra dirinya. Dan untuk menjaga performance dan peran sosial yang sedang disandangnya sebagai pemuka agama. Dalam beberapa kasus mereka juga menolak menjadi imam karena merasa kurang pas saat sedang memakai pakaian kaos dan tidak memakai peci.

Ketiga, Imam Mandiri. Berbeda dengan kategori imam citra, mereka yang termasuk dalam kategori ini tidak berpretensi untuk menunjukkan kehebatan dan keunggulan dirinya saat menjadi imam shalat. Mereka cenderung abai terhadap realitas jama'ah dikarenakan kepentingan pribadi yang biasanya bersifat kondisional, mereka biasanya bertipikal cuek, mengikuti selera dirinya. Surat yang dipilih, pakaian yang dipakai, bacaan panjang atau pendek bergantung kepada selera dirinya saja.

Perilaku cueknya juga ditunjukkan dengan cara berpakaian. Memakai baju koko, peci, dan atributatribut lainnya ketika dipakai dalam shalat tidaklah menjadi suatu pertimbangan bahkan bukan hal terpenting dalam shalat.

Keempat, Imam Ideal-Literalis. Imam dalam kategori ini berusaha 
semaksimal mungkin melaksanakan shalat sesuai kaidah teks hadis termasuk di dalam shalat berjama'ah. Pilihan surat dan panjang pendeknya ayat atau surat yang dibaca dan bahkan sampai kepada fiqh yang dipakai berdasarkan ketentuan teks yang diyakininya.

Dalam hal berpakaian mereka lebih mementingkan kerapihan, bersih, sopan, dan menutup aurat. Bagi mereka memakai peci, koko atau atribut lainnya bukan merupakan hal yang prinsipil. Baginya menjadi imam merupakan amanah dan hanya bisa diterima shalat oleh Allah manakala berperilaku ikhlas apalagi dalam menjalankan ibadah shalat. Sebagaimana Rasulullah mengajarkan kita shalat, maka kita pun wajib mengikuti amalan-amalan dan ajaran yang harus kita patuhi, terlebih saat kita mengerjakan iabadah shalat.

\section{Kesimpulan}

1. Peran Imam Masjid di provinsi Riau dapat dilihat dalam beberapa hal: pertama, pemersatu umat islam; kedua, menghidupkan semangat musyawarah; ketiga, membentengi aqidah umat; keempat, menjadi uswah bagi jamaah; kelima, menjadi rujukan dalam masalah keislaman; dan keenam, membangun soliditas jamaah

2. Tipologi imam shalat di Provinsi Riau, Pertama, imam kompromis-kondisonal. Dalam kategori ini gaya seorang imam lebih merupakan hasil kompromi dan afirmasi dari keinginan jamaah; Kedua, imam "CitraSensasional". Ketiga, Imam Mandiri, berbeda dengan kategori imam citra, mereka yang termasuk dalam kategori ini tidak berpretensi untuk menunjukkan kehebatan dan keunggulan dirinya saat menjadi imam shalat. Keempat, Imam Ideal-Literalis. Imam dalam kategori ini berusaha semaksimal mungkin melaksanakan shalat sesuai kaidah teks hadis termasuk di dalam shalat berjama'ah. 


\section{Daftar Kepustakaan}

Abu Daud (t.th.). Ain al-Ma'bud. Beirut: al-Maktabah alSalafiyah.

Ahmad Warson Munawir. (1997). alMunawwir: Kamus ArabIndonesia, Yogyakarta: Pustaka Progresif.

al-Asqalani, al-Imam al-Hafidz Ahmad bin Ali bin Hajar. (t.th.). Fathul Bari Syarh Shahih alBukhari. Beirut: Dar alMa`rifah.

Charon, Joel M. (1979). Symbolic Interaktionisme, an Introduction, an Interpretation, an Integration. London: Prentice-Hall.inc.

Deddy Mulyana. (2001). Ilmu Komunikasi Suatu Pengantar. Bandung: Remaja Rosdakarya.

Departemen Agama RI. (1999). alQur'an dan Terjemahannya. Semarang: CV. Asy-Syifa.

Glasse, Cyrl. (1999). Ensiklopedi Islam. Terj. Ghufron A. Mas'adi. Jakarta: Raja Grafindo Persada.

IAIN Syarif Hidayatullah. (1992). Ensiklopedi Islam Indonesia. Jakarta: Djambatan.

Ibnu Hambal, Ahmad. (1974). Betulkah Shalat Anda. Terj. Umar Hubeis Bey Arifin. Jakarta: Bulan Bintang.

Ibn Ruysd. (1982). Bidayah alMujtahid wa Nihayah alMuqtashid. T.tp.: Dar alMa rifah.
Jaib, Sa'di Abu. (1998). al-Qamus alFiqh Lughatan wa Ishtilahan. Suriah: Dar al-Fikr.

al-Jaziri, Abdur Rahman. (2004). alFiqh ‘ala al-Mazahib alArba`ah. Juz 2. Istanbul: Maktabah al-Hakikat.

al-Maududi, Abul A'la. (1984). Dasar-dasar Islam. Terj. Achsin Mohammad. Bandung: Pustaka.

an-Nisaburi, Muslim bin al-Hajjaj alQusyairi. (1991). Shahih Muslim. Kairo: Dar al-Hadits.

. (1954). Shahih Muslim Syarah al-Nawawi, Kitab al-Masajid wa Mawadhi'u al-Shalat. Indonesia: Maktabah Dahlan.

an-Nawawi, Imam. (t.th.). Minahaju at-Thalibin. Beirut Libanon: Daaral-Kutubal-Ilmiyah.

al-Qaradhawi, Yusuf. (2001). Madkhal li Dirasat al-Syari'ah al-Islamiyah. Kairo: Maktabah Wahbah.

al-Qazwaini, al-Hafizh Abi Abdillah Muhammad bin Yazid. (2008). Sunan Ibn Majah. Beirut: Dar al-Fikr.

al-Qurtubi. (t.th.). Jami' al-Ahkami al-Fiqhiyah. Beirut Libanon: Daaral-Kutubal-Ilmiyah.

al-Sadlan, Syaikh Shalih Ghanim. (1414 H). Shalatul Jama'ah. T.tp.: DarulWathan.

Saurah, Abi Isa Muhammad bin Isa bin. (1994). Sunan at-Tirmidzi. Beirut: Dar al-Fikr.

ash-Shabuni, Muhammad Ali. (2008). Rawa'i al-Bayan fi Tafsir Ayat al-Ahkam min al-Qur'an. 
Diterjemahkan Mu'ammal Hamidy dan Imron A. Manan. Terjemahan Ayat Ahkam ashShabuni. Surabaya: PT. Bina Ilmu.

al-Syirazi. (2002). "al-Muhadzab fi

Fiqh al-Imam al-Syafi'i

Radhiya Allahu 'anh". Dalam

Jaih Mubarok. Modifikasi

Hukum Islam: Studi tentang Qawl Qadim dan Qawl Jadid. Jakarta: Raja Grafindo Persada.

al-Suyuthi, al-Imam al-Hafizh Abi alFadhl Jalal al-Din Abd alRahman (1998). al-Tausyih Syarh al-Jami' al-Shahih, Kitab al-Shalat Bab Fadh Shalat alJama'ah. Jilid 2, Hadis no. 688. al-Mamlakah al-Arabiyah alSu`udiyah: Maktabah al-Rusyd.

T.M. Hasbi Ash-Shiddieqy. (1954). Pedoman Shalat. Jakarta: Bulan Bintang.

The Liang Gie dan Andrian. (2001). Ensiklopedi Ilmu-ilmu.
Yogyakarta: Gadjah Mada University Press.

Tim Penyususn. (1997). Ensiklopedi Umum. Yogyakarta: Kanisius.

Tim Penyusun. (2005). Ensiklopedi Islam. Jakarta: PT. Ichtiar Baru Van Hoeve.

Tim Penyusun. (1990). Kamus Besar Bahasa Indonesia. Jakarta: Balai Pustaka.

Tim Penyusun. (1996). Ensiklopedi Hukum Islam. Jakarta: PT. Ichtiar Baru Van Hoeve.

Tri Rama K. (t.th). Kamus Lengkap Bahasa Indonesia. Surabaya: Mitra Pelajar.

Walsh and Lehnert. (1972). The Phenomenology of the Social World. T.tp.: Heinemann Education. 